\author{
Maria Elżbieta JASTRZĘBSKA, PhD, Professor of the University of Gdańsk \\ Faculty of Management, University of Gdańsk \\ e-mail: maria.jastrzebska@ug.edu.pl \\ ORCID: 0000-0002-0027-930X
}

DOI: $10.15290 /$ oes.2019.04.98.03

\title{
STATE ACTION AIMED AT LIMITING FINANCIAL EXCLUSION IN POLAND IN TERMS OF SUSTAINABLE AND INCLUSIVE DEVELOPMENT ${ }^{1}$
}

\begin{abstract}
Summary
Puppose - The article was written to outline the State action (specifically central government's) aimed at limiting financial exclusion in Poland in terms of sustainable and inclusive development in 2016-2019.

Research method - In the article theoretical research is carried out on the basis of the subjective literature, existing legal requirements, international institutions' and central government's reports. Such research methods as descriptive analysis and inferential and inductive reasoning were used. First, financial exclusion is defined as a kind of social exclusion in the field of sustainable and inclusive development. Next, the author describes the most important central government's activity aimed at limiting financial exclusion in 2016-2019 in three areas. It is analysed how the State affects household income through fiscal policy instruments. The most important legal regulations affecting entities offering financial services and their clients are also pointed out. Finally, the State activity aimed at improving financial education and financial allowance of the Polish people is described.

Results - The article allows a better understanding of the State activity aimed at limiting financial exclusion in Poland undertaken in 2016-2019 with particular reference to fiscal policy instruments affecting household income.

Originality / value - To the best of author's knowledge, it is the only article concerning, as defined above, the three areas of the State activity aimed at limiting financial exclusion in Poland during the period considered, namely fiscal policy affecting household income; the most important legal regulations affecting entities offering financial services and their clients; improving financial education and financial allowance of the Polish people. It is very important considering sustainable and inclusive development.
\end{abstract}

Key words: financial exclusion, public finance, state policy

JEL Classification: A1, D1, H5

${ }^{1}$ Article received on 28 April 2019, accepted on 9 September 2019. 


\section{Introduction}

The State affects income distribution by setting minimum wage, the tapes and the amount of taxes as well as by delivering public goods free of charge or chargeable. In the same way, the State influences income distribution and distribution of goods produced by the society with the aim of achieving social justice through higher tax burden for richer population groups and in order to support poorer population groups and also less developed regions. In addition, by providing public and social goods, the State influences the allocation of resources in the economy for the factors of production to be used in an effective way. The State also undertakes actions to limit negative effects of the economic activity (for instance, in the area of environmental degradation) and to promote positive effects of the economic activity (for example, public expenditure on research and development).

The purpose of this article is to discuss central government's activity aimed at limiting financial exclusion in Poland in terms of sustainable and inclusive development. The areas discussed are: instruments of fiscal policy affecting household income (revenue and expenditure instruments); the most important legal regulations affecting entities offering financial services and their clients; the activities aimed at improving financial education and financial allowance of the Polish society.

\section{Sustainable and inclusive development - limiting social exclusion phenomenon}

Effective accomplishment of basic State function should be subordinated to implement the idea of sustainable and inclusive development. Sustainable development is the transition process which tries to meet the needs of the present generation, without reducing the chances of the next generation, through integrated action on economic and social development and environmental protection. However, the concept of inclusive development is not only about GDP growth, but also about the distribution of the benefits of GDP growth and equalisation of income and property inequalities. Social and economic stratification leads to radicalisation and stimulates populist sentiments while negatively affecting economic growth [www 1].

In 2015, the United Nations adopted Agenda for Sustainable Development 2030 in which seventeen sustainable development goals are defined [United Nations Agenda..., 2015]. The key political document with the help of which the goals of Agenda 2030 will be implemented in Poland is Strategy for Sustainable Development. In addition, among the five operating objectives of EU 2020 (Strategy of European Union) there is promoting social integration by limiting poverty, next to the objectives regarding employment, research and innovation, climate change and energy as well as education [Strategia Europa 2020, 2010]. 
The main goal of Strategy for Sustainable Development is to create conditions for income increase for the people who live in Poland whilst maintaining social, economic, environmental and territorial cohesion. The presumed effect of this Strategy is an increase in average income in Poland to $76-80 \%$ of the EU average income by 2020, and by 2030 a more rapid convergence in average income between households in Poland and the EU while limiting differences in income between regions in Poland and limiting the number of people threatened with poverty [Strategia na rzecz. odpowiedzialnego..., 2017].

There could be observed an increase in prosperity of Poland measured by GDP growth taking into account the per capita purchasing power parity. The level of this indicator increased from $50 \%$ of the EU average in 2005 to $68 \%$ in 2016 and $71 \%$ in 2018 [Wykonanie budżetu państwa..., 2018; www 2]. However, it is important to point out that economic growth does not proportionally reflect prosperity growth [Eurostat]. The level of income inequality in Poland is the highest among the countries of Central and Eastern Europe, because 10\% Poles with the highest income account for almost $40 \%$ of national income. The level of this participation in Europe is $37 \%$, in China it is $41 \%$, in Russia $46 \%$, in the USA $47 \%$, in SubSaharan Africa 54\%, in India and Brazil 55\% and in the Middle East 61\% [Alvaredo et al., 2018; Przepaśí miedsy bogatymi a ..., 2019].

Due to the chosen issue, at least three of these goals (table 1) are worth analysing. In 2017, compared to 2015, we may notice a decrease in the share of people at risk of poverty and social exclusion (from $27.8 \%$ to $19.5 \%$ ); the at-risk of poverty rate after social transfers (from $17.6 \%$ to $15.0 \%$ ); the at-risk of extreme poverty rate (from $6.5 \%$ to $4.3 \%$ - table 1 ).

The share of general government spending on essential services (education, health care and social protection) in total general government spending is rather high and in the period between 2010 and 2017 was at the rate of over 58-63\% (16$17 \%$ of GDP). Among them, spending on social protection has the highest share and it accounted for 35-37\% between 2010 and 2015, and over 40\% between 2016 and 2017. The share of spending on health care in public expenditure in the years 2010-2017 remained stable at about 11\%. In the case of spending on education it was about 12\%. The highest GDP per capita growth could be observed in 2011 and 2017 (5\% and 4.8\% respectively), and a decrease in unemployment rate between 2015 and 2017 (from 7.5\% to 4.9\%). What was also observed was an increase in: participation rate in organized learning, proportion of people with basic or above basic digital skills, number of bank branches and number of ATMs per 100000 adult population (table 1).

It is worth mentioning that the World Economic Forum drew up the ranking of 103 countries on the basis of the value of inclusive development index (ID index). The countries were divided into two groups - developed and emerging ones [Bakowska et al., 2019, p. 11]. In the top five of the developed countries there were: Norway (6.08), Island (6.07), Luxembourg (6.07), Switzerland (6.05) and Denmark (5.81). Poland, with the value of 4.61, ranked fifth among the emerging countries, 
whereas Lithuania scored 4.86, Hungary 4.74, Azerbaijan 4.69 and Latvia 4.67 [The Inclusive Growth and ..., 2018].

TABLE 1

Selected indicators by goals of sustainable development in Poland in the years 2010-2017 (\%)

\begin{tabular}{|c|c|c|c|c|c|c|c|c|}
\hline Specification & 2010 & 2011 & 2012 & 2013 & 2014 & 2015 & 2016 & 2017 \\
\hline \multicolumn{9}{|c|}{ Goal 1 No poverty } \\
\hline $\begin{array}{l}\text { Share of people at risk } \\
\text { of poverty or social } \\
\text { exclusion }\end{array}$ & 27.8 & 27.2 & 26.7 & 25.8 & 24.7 & 23.4 & 21.9 & 19.5 \\
\hline $\begin{array}{l}\text { At-risk of poverty rate } \\
\text { after social transfers }\end{array}$ & 17.6 & 17.7 & 17.1 & 17.3 & 17.0 & 17.6 & 17.3 & 15.0 \\
\hline $\begin{array}{l}\text { Share of general } \\
\text { government spending } \\
\text { on essential services } \\
\text { (education, health care } \\
\text { and social protection) } \\
\text { in total general } \\
\text { government spending } \\
\text { in this } \\
\text { - health care } \\
\text { - education } \\
\text { - social protection }\end{array}$ & $\begin{array}{l}58.6 \\
10.9 \\
12.1 \\
35.6\end{array}$ & $\begin{array}{l}58.3 \\
10.6 \\
12.4 \\
35.3\end{array}$ & $\begin{array}{l}59.7 \\
10.8 \\
12.5 \\
35.3\end{array}$ & $\begin{array}{l}60.9 \\
10.9 \\
12.4 \\
36.4 \\
\end{array}$ & $\begin{array}{l}60.9 \\
11.0 \\
12.4 \\
37.6\end{array}$ & $\begin{array}{l}61.6 \\
11.2 \\
12.7 \\
37.7\end{array}$ & $\begin{array}{l}63.9 \\
11.3 \\
12.1 \\
40.5\end{array}$ & $\begin{array}{l}63.3 \\
11.4 \\
11.0 \\
40.0\end{array}$ \\
\hline $\begin{array}{l}\text { At-risk of extreme } \\
\text { poverty rate }\end{array}$ & 5.8 & 6.8 & 6.8 & 7.4 & 7.4 & 6.5 & 4.9 & 4.3 \\
\hline \multicolumn{9}{|c|}{ Goal 4 Quality education } \\
\hline $\begin{array}{l}\text { Participation rate in } \\
\text { organized learning }\end{array}$ & 95.4 & 94.8 & 94.4 & 93.4 & 94.0 & 94.1 & 95.9 & 96.7 \\
\hline $\begin{array}{l}\text { Percentage of people } \\
\text { with basic or above } \\
\text { basic digital skills }\end{array}$ & & . & . & . & . & 40.1 & 44.4 & 46.4 \\
\hline \multicolumn{9}{|c|}{ Goal 8 Decent work and economic growth } \\
\hline $\begin{array}{l}\text { Growth of GDP } \\
\text { per capita }\end{array}$ & 3.5 & 5.0 & 1.6 & 1.5 & 3.4 & 3.9 & 3.1 & 4.8 \\
\hline Unemployment rate & 9.6 & 9.6 & 10.1 & 10.3 & 9.0 & 7.5 & 6.2 & 4.9 \\
\hline $\begin{array}{l}\text { Share of social } \\
\text { protection costs in } \\
\text { GDP }\end{array}$ & 16.7 & 15.8 & 15.9 & 16.3 & 16.2 & 16.0 & 16.9 & 16.4 \\
\hline $\begin{array}{l}\text { Number of commercial } \\
\text { bank branches and } \\
\text { ATMs per } 100000 \\
\text { adults }\end{array}$ & 85.8 & 87.4 & 92.0 & 91.5 & 92.2 & 94.5 & 97.6 & 116.6 \\
\hline
\end{tabular}

Source: [www 3]. 
Limiting social exclusion which regards these citizens who want to, but cannot participate in ordinary social live is very important in sustainable and inclusive development. This type of exclusion might be reflected in limiting access to resources and means [Szopa, Szopa, 2011, p. 13]. Social exclusion is analysed taking into consideration aspects of poverty, unemployment, social discrimination and may result from physical condition (disability, old or very young age), structural reasons (place of residence, poor education, income below the poverty line), morality (alcohol abuse, drug abuse, crime) or material condition (poverty and unemployment) [Diagnoza spoteczna ..., 2015].

\section{The essence of financial exclusion and the classification of central government's activities aimed at limiting this phenomenon in Poland}

In the countries of Central and Eastern Europe social exclusion causes financial exclusion, but in the countries of Western Europe financial exclusion is primary to social exclusion [Iwanicz-Drozdowska, Nowak, 2011, p. 27]. Financial exclusion refers to a process whereby people encounter difficulties accessing and/or using financial services in the mainstream market that are appropriate to their needs and enable them to lead a normal social life in the society in which they belong [Financial Services Provision..., 2008]. With regard to the form of financial services, the following types of exclusion can be identified: transaction, savings, credit, insurance, investment and retirement [Koźliński, 2010].

Financial exclusion may be caused by self-exclusion in the use of financial services, difficulties in the use of financial services or refusal of access to financial services by financial institutions. The reasons of financial exclusion on the side of clients of financial institutions are as follows: professional and social status (homeless people, disabled people, single parents); level of education (poor financial education and poor financial awareness); income received (poverty, poor material situation, losing debt sustainability); place of residence (small villages or towns) and digital exclusion; age (elderly people and very young people); attitude to financial institutions (reluctance to use them); attitude to new technology (e.g. reluctance to use fintech) and risk appetite (e.g. lack of confidence). The reasons of financial exclusion on the side of financial institutions (especially banks) are as follows: a limited number of bank branches, rising charges for financial services, market conditions and competition between financial institutions [Martyniuk, 2015, pp. 5758].

The State, by its regulatory function, may create conditions that encourage or discourage expansion of the financial sphere in the economy, the so-called financialisation, understood as the supremacy of financial sector over real economy [Marszałek, 2012, p. 221]. Monetary policy and fiscal policy encourage intensification of financialisation. Monetary policy based on low interest rate may lead to an increase in credit supply and borrowing, encourage looking for an alternative form of investment (investment funds instead of bank deposits) and cause 
speculation bubbles (especially at real estate market). Fiscal policy may influence financialisation by tax regulations, for example, by limiting the progressiveness of the tax scale and therefore increasing household income. It also contributes to investing financial surpluses in financial instruments. Furthermore, the higher the general government borrowing requirement is, the greater is the incentive to create financial instruments related to risk assessment of government securities. And if the State ensures access to some public and social goods for people with lower, compared to average, income by stimulating mortgage credit supply, household debt to a financial institution is growing. This situation encourages financial institutions to create financial instruments hedging the most risky credits. The State should also secure the living conditions for the elderly people and look for some methods to reduce budget expenditure, especially on financing social insurance funds, and methods which cause a rise in retirement funds, financial market and financialisation. The state investment funds (for example, Polish Development Fund, Local Investment Fund) also play an important role in stabilizing the financial system and the economy and in increasing financialisation [Ratajczak, 2012, pp. 293-295]. But besides that, people want to use financial services to fulfil a growing number of needs with regard to gaining money, making payments, savings, borrowings, insurance and long term investment in higher pension [Waliszewski, 2016, pp. 17$18]$.

The central authorities contribute to limiting social and financial exclusion affecting: household income (by using revenue and expenditure instruments of fiscal policy); institutions offering financial services (by introducing legal regulations); financial education and financial awareness of the Polish society.

\section{Affecting household income by using revenue instruments of fiscal policy}

The State intervenes in social and economic development by carrying out its social function. Therefore, a redistributive function plays a special role among modern State functions. The State is involved in the distribution of GDP with the aim of reducing social inequalities, which would arise in unlimited market mechanism. This function is carried out by fiscal policy in compliance with sustainable and inclusive development. The most important fiscal policy objectives are as follows: ensuring balanced State budget in the long term; financing a sufficient supply of public and social goods; using the State budget to stabilize social and economic development by equitable division of income and property ensuring a decent standard of living for the elderly, sick and unemployed people [Leszczyńska, 2013, p. 157-159].

First of all, the State affects household income by determining minimum wages and pensions and the minimum hourly rate. In addition, the central and local government determine the wages in the general government sector with regard to wages in the private sector and prices of consumer goods and services. It also 
influences the average wage in the economy and disposable income attributed to each household member (table 2).

TABLE 2

Minimum wage, minimum hourly rate, minimum pension, average wage in the economy, disposable income in the years 2012-2019 (PLN)

\begin{tabular}{|l|c|c|c|c|c|c|c|c|}
\hline \multicolumn{1}{|c|}{ Specification } & $\mathbf{2 0 1 2}$ & $\mathbf{2 0 1 3}$ & $\mathbf{2 0 1 4}$ & $\mathbf{2 0 1 5}$ & $\mathbf{2 0 1 6}$ & $\mathbf{2 0 1 7}$ & $\mathbf{2 0 1 8}$ & $\mathbf{2 0 1 9}$ \\
\hline Minimum wage & 1500 & 1600 & 1680 & 1750 & 1850 & 2000 & 2100 & 2250 \\
\hline $\begin{array}{l}\text { Minimum } \\
\text { hourly rate }\end{array}$ & 9.8 & 10.5 & 11.0 & 11.4 & 12.1 & 13.1 & 13.7 & 14.7 \\
\hline Minimum pension & 799.18 & 831.15 & 844.45 & 880.45 & 882.56 & 1000.0 & 1100.0 & 1100 \\
\hline $\begin{array}{l}\text { Average wage in } \\
\text { economy }\end{array}$ & 3399 & 3650 & 3783 & 3899 & 4047 & 4271 & 4585 & - \\
\hline $\begin{array}{l}\text { Disposable } \\
\text { income }\end{array}$ & 1278 & 1299 & 1340 & 1386 & 1475 & 1598 & 1693 & - \\
\hline
\end{tabular}

Source: [www: 4, 5, 6, 7, 8].

We may notice the minimum wage increase of 21.6 percentage points in 20162019, but in 2013-2015 the increase of 15.6 percentage points. Moreover, the minimum pension increase of 24.6 percentage points in 2016-2019, but in 20132015 the increase of 6.2 percentage points. The average wage in the economy increase of 13.3 percentage points in 2016-2018, but in 2014-2016 the increase of 7 percentage points. What can also be observed is the increase of disposable income of 14.8 percentage points in 2016-2018, but in 2014-2016 the increase of 10.1 percentage points. The disposable income is expected to increase also in 2019 because the government will perform the final application of the so-called "Kaczyński's Five" (for example, higher minimum wage and minimum pension, and extra pension for each pensioner).

The State affects household income also through taxes, by determining types of taxes, tax rates, the amount exempt from tax, tax relief and tax payment. Direct taxes such as Personal Income Tax (PIT) and Corporate Income Tax (CIT) are the instruments of redistributing household income (from contract work and business activity). These taxes determine household income and household purchasing power [Wiatrowski, 2018, p. 82].

It is worth mentioning that in the period between 2017 and 2019 a lower tax rate in CIT for new and small businesses was introduced. What is also worth noticing is an increase in the amount free of personal income tax (from 3091 PLN in 20082017 to 6600 PLN in 2018 and 8000 PLN in 2019). This year the government is preparing some changes in PIT, for instance, tax rate reduction from $18 \%$ to $17 \%$, an increase in tax deductible expenses, income tax exemption for people under the age of 26. On the other hand, this year sees an introduction of solidarity tribute ("danina solidarnościowa") concerning taxpayers of PIT who achieved the income 
of over 1 million PLN (tax rate 4\%; funds from this quasi-tax are the revenue stream of the Disabled Support Fund). Indirect taxes such as Value Added Tax (VAT) and excise duties are determined by companies and result in the price level and price structure. The State determines taxable goods and services, tax rate and in this way affects the level and structure of demand. These taxes have an impact on consumption patterns in a hidden way and the scale of this impact differs. These taxes are more acute for poorer rather than for richer households.

\section{Affecting household income by using expenditure instruments of fiscal policy}

The State also affects household income by public expenditure, mainly from the state budget. Such expenditure is divided into two categories - active expenditure contributing to human capital growth and passive expenditure contributing to strengthening household purchasing power by social transfers and to limiting social and financial exclusion [Caynmy swiat lepsaym ..., 2018].

The central government has a number of programs aimed at financially supporting families with children and also for the elderly and disabled people, and a significant increase in expenditure on social protection may be observed since 2016. This shows that current authorities reject the previous social policy institutional pluralism and the effects of four reforms: education, territorial government, pension and health care system [Zgliczyński, 2017, p. 4].

The "Family 500 plus" program plays a significant role among programs of financial support for families. It is aimed at providing financial assistance for families with children and thus preventing the demographic decline. The monthly financial assistance for the second and each new child is tax-exempt. The financial aid for the first child since April 2016 till June 2019 has depended on income criteria - the maximum of 800 PLN per person, but since July 2019 the income criterion will be abolished. So far the government has spent 67 billion PLN on financial assistance for 3.6 million children (in 2019 and 2020 financial assistance will encompass 6.8 million children and it will cost approximately 70 billion PLN). In the period of 2016-2017 an increase of $12.4 \%$ (from 1.32 to $1.47 \%$ ) in fertility rate was observed. Additionally, a decrease of $33 \%$ (from $6.5 \%$ in 2015 to $4.3 \%$ in 2017) in extreme poverty rate among children could be observed as well as a decrease of $6 \%$ (from $23.9 \%$ in 2015 to $17.9 \%$ in 2017) in the number of children endangered by poverty and social exclusion.

It is difficult to determine the effects of this program fairly, because its goals are formulated in a rather general way and indicators for measuring them are not specified. Among social policy instruments there is also lack of synchronization of the "Family 500 plus" program with other instruments of financial support for families with children. The financial assistance from this program may positively affect the income of households with children and their credit standing, but its influence on birth rate is inconclusive. This program also enables a rise in consumer 
spending, which is good for real business and for higher employment [Gromada, 2018, pp. 234-235].

The central government also implements two programs aimed at supporting child care - "Little man plus" and "Good start". In 2018 and 2019, 450 million PLN are planned to be spent year by year (earlier it was 151 million PLN year by year) under the first program. The planned results of the program in 2015-2018 encompassed an increase in the number of centres for children of up to three years of age (over 2000 ) and an increase in the number of places available for the children (about 59 000). Under the second program 1.44 billion PLN was spend in 2018 on 4.64 million learners of up to 18-20 years of age (the program continues in 2019). The central government has also started a new program (meant to be delivered in the years 2019-2022) for the poorest adults and children. It is entitled "Meal at school and at home" and its planned budget is 2.75 billion PLN. Another new program is "Mother plus". It is aimed at providing money for those mothers/fathers of the minimum of four children who receive pension which is lower than the minimum pension (900 million PLN is planned to be spent year by year). The government has also prepared the so-called "Pregnancy plus" program which allows a refund of expenditure on medicines for pregnant women in case of their illness (20 million PLN is planned to be spent in 2019).

Furthermore, the central government is implementing three programs for the elderly people - "Elderly people's social activity 2014-2020" program; "Senior plus" program - financial assistance for the local government to create institutional facilities for the elderly people in the communities of no more than 40 thousand citizens; "Care 75 plus" program - financial assistance for the local government to provide care service for the elderly people in the communities of no more than 60 thousand citizens. The central government spent about 270 million PLN in 20152018 on the second program. There could be observed an increase in the number of institutional facilities over 450 thousand and an increase in the number of places they offer about 11 thousand (considering the ageing Polish population, it is not enough). The central government spent about 57 million PLN on the third program in the same period of time. These programs will be continued.

This year, some changes are being implemented in the system of supporting people with disabilities and their families. The system is based on three pillars. The first of them is Solidarity Fund for Supporting People with Disabilities financed by part of the contribution from salaries paid into the Labour Fund and solidarity tribute. The second one is the package of social responsibility in the form of relief, rehabilitation allowances, privileges for the disabled, provisions from the Rehabilitation of Disabled People State Fund. The third one is "Accessibility plus" program aimed at removing obstacles in public space which limit the accessibility for the elderly, the disabled, pregnant women and parents with small children.

In 2019, "From exclusion to activation" program was launched for the people struggling with professional and social exclusion (planned budget of 3.4 million PLN). The aim of this program is to support social integration clubs; projects of social and professional assistance for the unemployed people; educational, 
prophylactic, social and therapeutic activities for young people threatened with social exclusion.

Last year, "Flat plus" program was introduced with the aim of increasing access to housing for the people who are not able to buy or hire a flat on market terms or for those threatened with social exclusion. The program is also aimed at improving housing conditions and housing stock.

In the period of 2019-2022, Employees' Capital Plans will be introduced with the aim of supporting long-term savings for higher pension and to limit pension exclusion. The financial means collected in this way will be private property of the participants and will be allocated on the capital market. The State will contribute to the development of this form of long-term savings for retirement through the socalled "one-off" welcoming contribution in the amount of 250 PLN and an annual contribution in the amount of 240 PLN.

Lastly, it is interesting to consider the results of OXFAM Report 2018 (a confederation of 20 independent charitable organizations focusing on the alleviation of global poverty) on income inequality. In the Report 157 countries were classified concerning Commitment to Reducing Inequality Index (CRI Index). The Index is based on the data from three areas. The areas are: social expenditure (expenditure on education, public health care, social protection and social benefits) in percent of total public expenditure and in percent of GDP; taxation - tax revenue as the share of GDP, how progressive it is and how effective the government activities against tax avoidance are; workers' rights and minimum wage. According to the value of CRI Index, Denmark ranked first (0.87), Germany second (0.84), Finland third (0.83), Austria fourth (0.83) and Norway fifth (0.83). Among the five countries which appear at the end of this ranking were: Nigeria (0.05), Uzbekistan (0.11), Haiti (0.12), Chad (0.13) and Sierra Leone (0.14). Poland ranked 20th according to value of CRI Index (0.69). However, regarding social expenditure, Poland came 1st, considering workers' rights and minimum wage -33 rd and taking into account taxation - 114th out of the 157 examined countries [The Commitment to ..., 2018].

\section{Affecting entities providing financial services}

The impact of financialisation of the socio-economic life is apparent in: searching for stability of general government, counteracting illiteracy in the financial area (activities aimed at stimulating the growth of financial literacy), caring for the effectiveness of legal security of financial turnover [Wiśniewski, 2014, p. 330]. Therefore, the State should limit the negative external effect of business activity of financial institutions and non-banking financial institutions that contribute to financial exclusion of certain individuals or social groups. Accordingly, the central authorities' activities rely on introducing and revising legal regulations, so as to decrease the scale of this phenomenon. The most important legal regulations in this area, introduced in the last three years, include the following: 
- the revision of the so-called Anti-usury Act - changes in the Consumer Credit Act and Financial Market Supervision Act aimed at protecting borrowers against excessive bank charges and overly high interest payments (2016 and 2017),

- the revision of Mortgage Credit Act and Supervision of Morgan Credit Brokers and Agents Act aimed at providing faster, safer and more efficient wholesale (2017),

- the revision of Payment Services Act aimed at stimulating the growth in cashless clearing and the development of information society (2018),

- the revision of Financial Market Supervision Act and Insurance and Reinsurance Activity Act aimed at reinforcing financial market supervision and strengthening the level of security of players on that market making use of collective investment products, insurance investment products, securitisation, services provided by web platforms - online payments, loans and insurance (2018),

- the revision of Fight Against Money Laundering and Financing Terrorism Act aimed at determining the new catalogue of institutions obliged to identify and report on the types of risk mentioned above (2018),

- the revision of Financial Assistance for Borrowers who got Mortgage Credit Act aimed at extending the period of functioning of Financial Assistance for Borrowers Fund (2018),

- the project of revision of Personal Bankruptcy Act aimed at allowing bankruptcy for a greater number of people than before (2018),

- the project of legal regulations aimed at providing financial support for borrowers who took Swiss franc loans (2016-2018).

The State should also care for the growth of microfinance institutions. Most commonly their objective is to promote micro-enterprises, job creation, social and economic inclusion, and to limit poverty. These institutions provide financial services for people with low income, the poor and financially excluded and for those who do not use traditional financial services [Alińska, 2017, p. 26]. The central and local authorities should support the creation of such entities (for example, municipal banks) first of all by introducing legal regulations for them [Adamski, 2016, p. 41].

The State also supports the growth of cashless clearing. The main role in this aspect is played by the Cashless Poland Foundation followed by banks initiative, card issuers, acquirers, VISA and MasterCard. It is supported by the Ministry of Entrepreneurship and Technology and by the Polish Banking Association. The general government entities and entrepreneurs who do not accept payment by payment cards as well as those who are starting their business activity may receive a card reader for free in the period from September 2018 till August 2021 (under certain conditions). Some legal regulations also support the growth of cashless clearing, for example, those contained in Personal Income Tax Act and Entrepreneurs Law Act. According to these regulations, spending over 15 thousand PLN are not deductive expenses (till 2017 that limit was 15 thousand EUR). Moreover, since 2019, according to Labour Code, an employer appointing an 
employee based on the work contract should pay his or her salary directly to the bank account specified by the employee, unless the employee submits an application for salary payment in cash.

\section{Influencing the growth of financial education and financial awareness of the Polish society}

Financial education should be a supplement to legal regulations aimed at enabling clients of financial institutions to receive appropriate information, consultancy and protection. This is relevant because the growth in scale and importance of financial institutions sector in the economic growth do not go hand in hand with understanding the processes in the financial market. This results in putting some members of the society in trouble and encourages building up of the negative socio-economic phenomenon. People with low financial literacy are susceptible to manipulation by financial institutions and non-financial institutions alike, and that deepens income inequalities [Gołębiowski, 2017, p. 114].

The precondition of economic growth is a well-functioning and conscious society. Therefore, financial education has to become one of the public goods and financial literacy needs to become a universal resource of human capital [Potocki, 2015, p. 282].

Financial education should protect individuals from financial exclusion and shape their financial awareness. It is the ability to understand how money works (how to save, invest, borrow and spend money wisely). It is possible to identify several major areas which observe an influence of financial literacy programs and where the results were measured. These are: greater likelihood to plan for retirement and bigger retirement accumulation; diverse asset portfolios; higher awareness in terms of borrowing decisions; better allocation of lifetime resources; increased planning and saving among low-income individuals; increased saving and planning behaviour among children and young adults [Batsaikhan, Demertzis, 2018, pp. 7-8].

Poland holds the last position with regard to the level of financial education of people aged between 18 and 79 among 31 countries of the world examined by the OECD. Three aspects were taken into consideration - knowledge, behaviour and attitude towards long-term financial planning (pensions). The average level of the index for 31 examined countries was 13.7 points (out of the 21-point maximum). The highest level of the index was 14.9 points for France and the lowest for Poland - 11.6 points, after Belarus with 11.7 points [Adult Financial Literacy..., 2016].

In accordance with OECD recommendations [Recommendation on Principles ..., 2005], each country should create and effectively implement national financial education strategy not only on a particular level of education. In addition, financial education of individuals in the sphere of consumption, behaviours on the labour market and entrepreneurship is also important. Financial education should be actively supported and should be available on a permanent basis at each life stage. Financial education programs should be adapted to their beneficiaries' special needs 
and access to these programs should be easy. The financial market participants should gain economic and financial knowledge early enough. Therefore, the public organs should take into consideration including this kind of knowledge into educational programs as a major subject. The economic and financial knowledge passed by entities offering financial services should be available in an honest, transparent and impartial form [Górski, 2016, pp. 151-152].

The Ministry of Finance, the National Bank of Poland and the Polish Banking Association promote financial knowledge via the media, publications, training and competitions. Local authorities and non-governmental organizations also play a special role in this field. They may promote lessons on the subject of finance in cooperation with financial institutions.

In accordance with the revision of Financial Market Supervision Act in 2018, Financial Education Fund and Financial Education Board, which mark the directions and means of task implementation, were established in Poland. The objective of the Fund is to improve financial education and raise financial awareness in the Polish society as well as to create a compensation system for natural persons who bought the bonds the issue or sales of which were performed with the violation of legal regulations. In addition, the Fund will spend money on financial awareness campaigns, national financial education strategy, financial education programs, publications on the issues concerning the financial market, cooperation with financial institutions and the Ministry of Education.

\section{Conclusions}

The State should care for the economic efficiency, social justice and economic stability. It does not only concern income growth, but also its distribution in the society. Poverty prevention, equal access to education, positive trends on the labour market, well-functioning health care system and social equality are solid foundations of the economic and social development in every country and in the global economy. Apart from that, it is very important to implement some solutions in the social and economic system which are good for inclusive development. These solutions enable a fuller extension of the market potential and counteract financial exclusion, a negative phenomenon at a time of financialisation of the economy and households.

\section{References}

Adamski R., 2016, Podstawowe zagadnienia zwiazane z funkecjonowaniem komunalnych kas oszcrędnościonych w Polsce, „Ekonomiczne Problemy Usług”, nr 125, s. 37-48, DOI: 10.18276/epu.2016.125-03.

Adult Financial Literacy Competencies, 2016, OECD, https://www.oecd.org/daf/fin/ financial-education/OECD-INFE-International-Survey-of-Adult-FinancialLiteracy-Competencies.pdf [date of entry: 28.12.2018]. 
Alińska A., 2017, Instytucje mikerofinansowe na rynku ustug finansowych, „Prace Naukowe Uniwersytetu Ekonomicznego we Wrocławiu”, nr 478, s. 24-36, DOI: 10.15611/ pn.2017.478.02.

Alvaredo F., Chancel L., Piketty T., Saez E., Zucman G., 2018, World Inequality Report 2018, https://wir2018.wid.world/files/download/wir2018-full-reportenglish.pdf [date of entry: 11.04.2019].

Batsaikhan U., Demertzis M., 2018, Financial literacy and inclusive growth in the European Union, "Policy Contribution", iss. n 08, http://bruegel.org/wp-content/ uploads/2018/05/PC-08_2018.pdf [date of entry: 28.12.2018].

Bąkowska K., Lachowicz M., Marczewski K., 2019, Indeks odpowiedzialnego rozwoju. PKB to za mało..., Lachowicz M. (red.), Polski Instytut Ekonomiczny, http:// pie.net.pl/wp-content/uploads/2019/02/ PIE-Indeks_Odpowiedzialnego_Rozwoju.pdf [date of entry: 28.03.2019].

Czyńmy swiat lepszym niz. go zastalismy, 2018, Ministerstwo Rodziny, Pracy i Polityki Społecznej, https://www.gov.pl/documents/1048151/1060973/Raport_Czy\%C 5\%84my_\%C5\%9Bwiat_lepszym.pdf/ea5f8ddd-ad6e-f65d-016c-dca85e7839f5 [date of entry: 28.12.2018].

Diagnoza spoteczna 2015. Warunki i jakość życia Polaków - Raport, 2015, Czapiński J., Panek T. (red.), „Contemporary Economics”, nr 9/4, http://www.diagnoza. com/pliki/raporty/Diagnoza_raport_2015.pdf [date of entry: 28.12.2018].

Financial Services Provision and Prevention of Financial Exclusion, 2008, European Commission, Brussels, http://ec.europa.eu/socialblopservices [date of entry: 28.12.2018].

Gołębiowski G., 2017, Finansyzacja żcia codziennego, [w:] Złota Ksiega dla Profesora Szczepańskiego, Ickiewicz J., Ostaszewski J. (red.), Oficyna Wydawnicza SGH, Warszawa.

Górski J., 2016, Alfabetyzacja ekonomiczna, çyli znaczenie swiadomości ekonomicznej, „Bezpieczny Bank”, nr 3(64), s. 142-158.

Gromada A., 2018, Cz̨emu stuð்y program „rodzina 500 plus”. Analiza celów polityki publicznej i polityki partyjnej, „Ruch Prawniczy, Ekonomiczny i Socjologiczny”, nr 3(80), s. 231-244, DOI: 10.14746/rpeis.2018.80.3.18.

Iwanicz-Drozdowska M., Nowak K., 2011, Rola i znaczenie edukacji finansowej, [w:] Edukacja i świadomość finansowa, Iwanicz-Drozdowska M. (red.), Oficyna Wydawnicza SGH, Warszawa.

Koźliński T., 2010, Wykluczenie platnicze w Polsce i innych krajach Unii Europejskiej, NBP, Warszawa, https://www.nbp.pl/systemplatniczy/wykluczeniefinansowe/ download/wykluczenie_platnicze_w_polsce_i_innych_krajach_ue.pdf [date of entry: 28.12.2018].

Leszczyńska M., 2013, Polityka fiskalna państwa a dochody polskich gospodarstw domowych, „Nierówności społeczne a wzrost gospodarczy”, nr 31, s. 156-166.

Marszałek P., 2012, Finansyzacja - problemy i kontrowersje, „Prace Naukowe Uniwersytetu Ekonomicznego we Wrocławiu”, nr 247, s. 220-230. 
Martyniuk M., 2015, Wykluczenie finansowe a podmioty mu przeciwdziatajace na prayktadzie Polski, „Studia Zarządzania i Finansów Wyższej Szkoły Bankowej w Poznaniu”, nr 9, s. 55-71.

Potocki T., 2015, Instytucjonalne uwarunkowania $i$ mechanizmy podnoszenia świadomości finansowej, „Prace Naukowe Uniwersytetu Ekonomicznego we Wrocławiu”, nr 395, s. 274-285, DOI: 10.15611/pn.2015.395.26.

Przepaść mięry bogatymi a biednymi w Polsce rośnie najbardziej w Europie, 2019, https:// tvn24bis.pl/pieniadze,79/nierownosci-dochodowe-w-polsce-i-w-europie-badanie -world-inequality-lab,924902.html [date of entry: 11.04.2019].

Ratajczak M., 2012, Finansyzacja gospodarki, „Ekonomista”, nr 3, s. 281-301.

Recommendation on Principles and Good Practices for Financial Education and Awareness, 2005, OECD, http://www.oecd.org/finance/financial-education/35108560.pdf [date of entry: 28.12.2018].

Strategia Europa 2020, 2010, http://ec.europa.eu/eu2020/pdf/1_PL_ACT_part1_v1. pdf [date of entry: 28.12.2018].

Strategia na rzecz, odpowiedzialnego rozwoju do roku 2020 (z. perspektywa do 2030 roku), 2017, Warszawa, https://www.gov.pl/web/inwestycje-rozwoj [date of entry: 28.12.2018].

Szopa B., Szopa A., 2011, Wykluczenie finansowe a nykluczenie spoteczne, „Zeszyty Naukowe/Polskie Towarzystwo Ekonomiczne", nr 11, s. 13-27.

The Commitment to Reducing Inequality Index 2018, 2018, OXFAM, https://www. oxfamamerica.org/explore/research-publications/the-commitment-to-reducinginequality-index-2018/ [date of entry: 11.04.2019].

The Inclusive Growth and Development Report 2018, 2018, World Economic Forum, http://www3.weforum.org/docs/WEF_Forum_IncGrwth_2018.pdf [date of entry: 28.12.2018].

United Nations Agenda 2030. Przelesżtałcamy nasz świat: Agenda na rzecz zrównoważonego rozwoju 2030, 2015, http://www.unic.un.org.pl/files/164/Agenda\%202030_pl_ 2016_ostateczna.pdf [date of entry: 28.12.2018].

Waliszewski K., 2016, Financialization of the Economy and the Need for Personal Finance Advisory Services, „e-Finanse”, nr 2(12), s. 13-23, DOI: 10.14636/1734-039X_I2_ 2_002.

Wiatrowski P., 2018, Polityka podatkowa państwa a nierówności społeczne, „Nierówności społeczne a wzrost gospodarczy, nr 54(2), s. 76-86, DOI: 10.15584/nsawg. 2018.2.5.

Wiśniewski P., 2014, Nowe miary finansyzacji, [w:] Roz̧wój nauki o finansach. Stan obecny ipożqdane kierunki jej ewolucji, Ostaszewski J., Kosycarz E. (red.), Oficyna Wydawnicza SGH, Warszawa.

Wykonanie budżetu państwa. Wystapienie w Sejmie Prezesa Najwyższej Izby Kontroli, 2018, „Kontrola Państwowa”, nr 4, https://www.nik.gov.pl/plik/id,18297.pdf [date of entry: 28.12.2018].

Zgliczyński W.S., 2017, Polityka społeczna w państwach UE - wydatki i rožwiqzania modelowe, „Infos”, nr 10(233). 
www 1, https://www.sciencedirect.com/topics/earth-and-planetary-sciences/sustainable-development [date of entry: 28.12.2018].

www 2, https://ec.europa.eu/eurostat/statistics-explained/index.php/GDP_per_capita,_consumption_per_capita_and_price_level_indices [date of entry: 11.09. 2019]. www 3, http://sdg.gov.pl/ [date of entry: 11.04.2019].

www 4, https://www.infor.pl/wskazniki/prawo-pracy-i-ubezpieczen-spolecznych/ wynagrodzenia, Minimalne-wynagrodzenie-za-prace [date of entry: 11.04.2019]. www 5, https://www.infor.pl/wskazniki/prawo-pracy-i-ubezpieczen-spolecznych/emerytury-i-renty [date of entry: 11.04.2019].

www 6, https://wynagrodzenia.pl/gus/dane-roczne [date of entry: 11.04.2019]. www 7, https://www.infor.pl/wskazniki [date of entry: 11.04.2019].

www 8, https://www.infor.pl/wskazniki/oplaty/277,Przecietny-miesieczny-dochod -rozporzadzalny-na-1-osobe.html [date of entry: 11.04.2019]. 